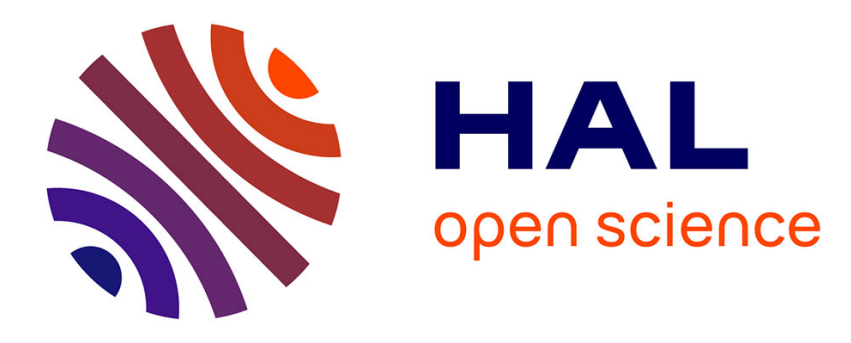

\title{
The Border City in a Border Country: the Case of Skopje \\ Goran Sekulovski
}

\section{To cite this version:}

Goran Sekulovski. The Border City in a Border Country: the Case of Skopje. Regions The Newsletter of the Regional Studies Association, 2008, 270 (1), pp.18-20. 10.1080/13673882.2008.8628869 . halshs-00315298v2

\section{HAL Id: halshs-00315298 \\ https://shs.hal.science/halshs-00315298v2}

Submitted on 2 Sep 2008

HAL is a multi-disciplinary open access archive for the deposit and dissemination of scientific research documents, whether they are published or not. The documents may come from teaching and research institutions in France or abroad, or from public or private research centers.
L'archive ouverte pluridisciplinaire HAL, est destinée au dépôt et à la diffusion de documents scientifiques de niveau recherche, publiés ou non, émanant des établissements d'enseignement et de recherche français ou étrangers, des laboratoires publics ou privés. 
Sekulovski, G. (2008). The Border City in a Border Country: the Case of Skopje. Regions Magazine 270, 1, 1820 [http://rsa.informaworld.com/srsa/content $\sim$ content $=a 901757357 \sim$ db=all $\sim$ order $=$ page ]

The definitive version is available at www.rsa.informaworld.com

(C) Regions Magazine, 2008 Informa UK (Taylor \& Francis)

\title{
The Border City in a Border Country: The Case of Skopje
}

\author{
Goran Sekulovski, University of Paris 1 Pantheon-Sorbonne
}

\section{Introduction}

The historical scheme of political development in the Balkans which does not go without provoking an important gap between the original and modern borders, physical or mythical, the real or the dreamed-off, is the source of numerous contemporary tensions of which border cities are exemplary. Without neglecting the importance of historical contexts which saw their birth and local conditions which saw their growth, they depend in effect, more than other entities, on a clear determination of the process which consists in "marking" or "remarking" the borders between the communities involved in situations of conflict, verily within them. One could even say that this process is their very being. Skopje, the capital of the Republic of Macedonia, presents, in its way, a rather complete picture of all these complexities.

How should this city, heir to Roman Scupi, Ottoman Uskup, capital of the new republic, born of the fall of former Yugoslavia, even the international recognition of which did not come without difficulties be qualified? Should it to be called a border city? This question is not a harmless one. The transformation of the imperial space, of which Skopje was a part, into a series of territorial Nation-States radically affected the image and functioning of the city. From a crossroads of diasporas, it became a pole of neonationalism, which made a border city of it (Prevelakis, 1996: 92-93). But that is not all. The political consequences of this mutation are also immense.

\section{Polarization between Macedonians and Albanians in the Capital}

Situated in one of the basins of the valley of Vardar River, the city unites two communities, Macedonians and Albanians, which have very marked differences but whose coexistence has shaped the most significant socio-political events of its history and has had a decisive impact on its development. This de facto bipartition brought about a strong ethnic and ideological polarization which is felt even today. Hence the process of stabilization begun with the Ohrid Framework Agreement, signed in August 2001, was intended to put an end to the conflict at first latent, then open, which for seven months opposed Albanian rebels to government security forces. 
Sekulovski, G. (2008). The Border City in a Border Country: the Case of Skopje. Regions Magazine 270, 1, 1820 [http://rsa.informaworld.com/srsa/content $\sim$ content $=a 901757357 \sim$ db $=$ all $\sim$ order $=$ page ]

The Ohrid Agreement put in place several reforms as fundamental as they are simple: the authorization of a broader official use of the Albanian language, the decentralization of administration by the strengthening of local power, and the guarantee of proportional representation in institutions to the Albanian part of the population. During the implementation of the agreement, however, a problem has quickly appeared which passes the simple level of practical difficulties: the very concept of the state as a public and civil space seemed menaced by communitarianism. Hence the clear mention in the Agreement (Sector, 2007: 1. Basic Principles) that there were not to be "territorial solutions to ethnic issues: the multiethnic character of Macedonia's society must be preserved and reflected in public life.'

\section{The new decentralization Law (2004) and the question of "bilingual Skopje"}

In a reverse of this logic, a Law on Territorial Organisation was advanced in 2004 which, while claiming itself on the Ohrid agreement, paradoxically contradicted its principals. Whence came the project for this Law? It was designed at the end of long, wearying and opaque negotiations by Macedonian and Albanian leaders who were members of a government coalition. This law caused debates all the more controversial within the country and abroad because it put directly into doubt the divisions and delimitations admitted in the capital. However if the Ohrid Agreement included a possible revision of decentralization such as was done in 1996, it did not envisage the drawing or redrawing of borders, and still less made on ethnic principle. The theoretical result was that, following the territorial map, the country was divided according to an ethnic principle and the interests of the citizenry were sacrificed for the government elites. The practical result was that Albanian became the second official language of Skopje and Albanians were imposed as the majority in the city of Struga on the Ohrid Lake.

Creating a bilingual Skopje demanded that the city's "borders" be redrawn: two neighbouring villages were added to the capital in order to increase the Albanian population from $15 \%$ to more than $20 \%$-which the Ohrid agreement posed as the condition for the recognition of a second official language in the capital. These are the municipalities of Saraj and Kondovo which increase the area of Skopje by $229 \mathrm{~km}^{2}$ and which count as borough villages of more then $20 \mathrm{~km}$ away from the capital. Since then the rural population represents $15 \%$ of the population of the capital, against only $6 \%$ before the decentralization. The prospective result is that the two communities are ever more called on to separate themselves: one can see here a phenomenon of dualization along the Vardar, between the "Left bank" abandoned to Albanians and the "Right bank" reserved by ethnic Macedonians. Certainly the 
Sekulovski, G. (2008). The Border City in a Border Country: the Case of Skopje. Regions Magazine 270, 1, 1820 [http://rsa.informaworld.com/srsa/content $\sim$ content $=a 901757357 \sim$ db $=$ all $\sim$ order $=$ page ]

river which physically bisects the city symbolizes the division in the manner of a mental barrier more than a border zone in the military or literary sense of the term, but it represents nonetheless the potential risk of outbursts which concerns the spirits as much at the level of the capital as of the country.

\section{Macedonian « fears »}

The enforced "bilingualism" of the capital affected civic practice, access to public services and resources in one's mother tongue and yet more the symbolic status of the city. The Macedonians feared not only lest the introduction of Albanian should bring about a situation of waste, but also lest the capital lose, in some way, its Slavic identity. It is one of the numerous signs of the endemic distrust that existed between the two communities and that still remains considerable: each side suspects the other's intentions and motivations, thus reinforcing a conspiratorial tendency inherent to the Balkan political culture.

Fear of an Albanian secession is aggravated by demographic curves, or at least their representation: the Albanians have a higher growth rate than the Macedonians and moreover, they live mostly in border zones of Kosovo and Albania. At the same time, it is necessary to remember that the demographic image of the capital has experienced a net change between the first post-war census, held in 1953, and the most recent, held after the implosion of Yugoslavia in 2002 (Statistical Office, 2005: 34). The number of ethnic Macedonians went from $63 \%$ to $71 \%$ and that of ethnic Albanians from $3 \%$ to $15 \%$ of a total of 467,527 in the capital in 2002. But since the new territorial organization of 2004, the Macedonians have formed the principal group in Skopje (66.75\%) followed by the Albanians (20.49\%) for a total population of 506,926 inhabitants.

Hence arises the fear of the ethnic Macedonians of losing "their" country, of having abandoned it to the Albanians. In a strained atmosphere where heated debates on national identity and the threats that surround it come together, most ethnic Macedonians see only one protector for their existence as a nation: the State.

\section{Conclusions}

How should we, without reverting to radical optimism or pessimism to find a new balance of "living together", between individualism and a mass men phenomenon, the person and the multitude, being and diversity? On the one hand there is the dominant conception founded on a sort of voluntary optimism. This current of thought easily lauds cohabitation, coexistence, differences, verily crossbreeding, there where mutual confidence is supposed to 
Sekulovski, G. (2008). The Border City in a Border Country: the Case of Skopje. Regions Magazine 270, 1, 1820 [http://rsa.informaworld.com/srsa/content $\sim$ content $=a 901757357 \sim$ db $=$ all $\sim$ order $=$ page ]

deepen and negative stereotypes in the perception of the Other go into a decline. Following this logic, the term "border city" to designate Skopje will refer to the zone of confluence more than to a line of demarcation. On the other hand, the historical analysis, which inclines towards a prudent pessimism, emphasizes in the contrary the fatality of communitarian logic. In the polarization of differences, is it not violence which comes confirm the identity, its wellfondness, its durability? Thus Debray (2005:158) feigns nicely to exclaim "Give me a border and a threat and I will make you a community: the grammar of civilizations has something inalterable."

Today, the challenge of the Western Balkans is held wholly in the expansion, or not, of the European Union. Macedonia registered its candidacy in March 2004 and in December 2005, the European Council ratified the decision, but without setting a date for the opening of adhesion negotiations. In the meantime, the border city of Skopje became the capital of a political and state entity itself transformed into a border-country. Thus, there will be no "European miracle". Between possible pacification and possible chaos, Skopje became the metaphor for Macedonia.

It would be moreover a grave delusion to believe that Macedonians and Albanians will suddenly change their civic attitude towards the state: national identity is, and will remain for a long time, defined in terms of ethnicity. The conflict is not, or is not only, between Macedonians and Albanians. It exists first and foremost between those who believe in a peaceful manner of tackling the mental border and those who do not. All research into the development of civic society must pass, as a prerequisite, by a singular concern of security, which is that of assuring to the people the full and free expression of their cultural identity. It is thus that the sick obsession for the ethnic and national questions will give way to the discovery of inter-culturalism and plurality. One ought not in consequence to underestimate the utility of a peaceful framework to control the divergences of affinities or interests which are perfectly normal in a plural city and of which plurality makes the unique value.

The mode of subjective intercultural coexistence-in the sense of subjects-which persists in Skopje, next to the objectivity of existing political and economic conditions, is without doubt one of the key elements for the survival of the Macedonian state.

\section{Bibliography and further reading :}

Debray, R. (2005). “A bout de souffle, l’Europe ?”. Medium 4, pp.155-167.

Gottmann, J. (2007). La politique des Etats et leur géographie. Paris: Editions du CTHS. 
Sekulovski, G. (2008). The Border City in a Border Country: the Case of Skopje. Regions Magazine 270, 1, 1820 [http://rsa.informaworld.com/srsa/content $\sim$ content $=a 901757357 \sim$ db=all $\sim$ order $=$ page ]

Heller, A. (1996). "The Many Faces of Multiculturalism” in Bauböck, R., Heller, A. and Zolberg, A. (Eds.). The Challenge of Diversity: Integration and Pluralism in Societies of Immigration. Avebury: Aldershot, pp. 25-42.

Hobsbawm, Eric J. (1990). Nations and nationalism since 1780. Programme, myth, reality. Cambridge, New York, Melbourne: Cambridge University Press.

Kotek, J. (1996). "Les villes-frontières au XX $X^{\mathrm{e}}$ siècle: 'Etre et ne presque plus être"” in Kotek, J. (Ed). L'Europe et ses villes-frontières. Brussels, Paris: Complexe, pp. 15-32.

Loomis, A., Davis, L. et Broughton, S. (2001). "Politics and Identity in Macedonia. Intrinsic versus Extrinsic Understandings". Paper presented at the conference Macedonia-Macedonias: Changing Contexts in the Changing Balkans, London, 14-16 June.

Prevelakis, G. (1996). "Istanbul, Skopje et Salonique: villes-frontières ou cités-carrefours ?" in Kotek, J. (Ed). L'Europe et ses villes-frontières. Brussels, Paris: Complexe, pp. 77-95. Sassen, S. (1996). "Analytic borderlands: race, gender and representation in the new city" in King, A. D. (Ed.). Re-presenting the city: ethnicity, capital, and culture in the 21st-century metropolis. New York: New York University Press, pp. 183-202.

Sector for the Implementation of the Ohrid Framework Agreement (2007). Framework Agreement.[online]. Available from <www.siofa.gov.mk/defaulten.asp? shema $=$ Voved\&temaID $=1 \&$ sodrzinaID $=16>$.

Sekulovski, G. (2007). "The City of Skopje: a Border or a Multicultural City ?" in Janicki, W. (Ed.), European multiculturalism as a challenge - policies, successes and failures, Political Geography Studies No.1, Lublin: Maria Curie-Sklodowska University and Polish Geographical Society, pp. 237-249.

Statistical Office of Macedonia (2005). Census of Population, Households and Dwellings in the Republic of Macedonia, 2002 Book XIII. Skopje: The State Statistical Office.

Todorova, M. (1997). Imagining the Balkans. New York-Oxford: Oxford University Press. United Nations Development Programme (1970). Skopje Resurgent. New York: United Nations. 